\title{
Development and psychometric properties of the Subtle Gender-Based Violence Among Medical Residents Assessment Scale (SGEVRA)
}

\author{
Diana Guízar-Sánchez, Ingrid Vargas-Huicochea, ${ }^{2}$ Aura Silva-Aragón, ${ }^{3}$ Gerhard Heinze, 'Luis Manjarrez-Gutiérrez, \\ Dewi Hernández-Montoya ${ }^{4}$ Ana Fresán-Orellana ${ }^{5}$
}

Subdivisión de Especialidades Médicas, Unidad de Posgrado de la Facultad de Medicina, Universidad Nacional Autónoma de México, Ciudad de México, México

2 Departamento de Psiquiatría y Salud Mental, Facultad de Medicina, Universidad Nacional Autónoma de México, Ciudad de México, Mexico.

3 Comisión de Género. Sistema de Universidad Abierta y Educación a Distancia, Universidad Nacional de Autónoma de México, Ciudad de México, México.

${ }^{4}$ Departamento de Investigación Epidemiológica, Instituto Nacional de Pediatría, Ciudad de México, México.

5 División de Investigación Clínica, Instituto Nacional de Psiquiatría Ramón de la Fuente Muñíz, Ciudad de México, México.

\section{Correspondence:}

Ana Fresán-Orellana

Departamento de Epidemiología Clínica, División de Investigación Clínica, Instituto Nacional de Psiquiatría Ramón de la Fuente Muñíz. Calz. México-Xochimilco 101

C.P. 14370, Ciudad de México, México.

Phone: +52554160 - 5069

Fax: +52555513- 3722

Email: fresan@imp.edu.mx

Received: 27 May 2019

Accepted: 5 September 2019

Citation:

Guízar-Sánchez, D., Vargas-Huicochea, I., Silva-Aragón, A., Heinze, G. Manjarrez-Gutiérrez, L, Hernández-Montoya, D., \& Fresán-Orellana, A. (2019). 'Development and psychometric properties of the Subtle Gender-Based Violence Among Medical Residents Assessment Scale (SGEVRA). Salud Mental, 42(5). 227-234

DOI: $10.17711 /$ SM.0185-3325.2019.029

\begin{abstract}
Introduction. Medical residents (MR) are an important pillar for a future effective health system. As such, it is important to study all the factors throughout their training that may influence their professional development, like gender-based violence (GV). Objetive. To design and evaluate the psychometric proprieties of subtle GV among medical residents' assessment scale (SGEVRA). Method. The design was carried out in two phases: (1) in the qualitative phase, three focus groups were interviewed to obtain information about GV during medical training; and (2) in the quantitative phase, the information was incorporated into the instrument and the psychometric properties were tested. Results. A total of 1,645 medical residents (MRs) completed the instrument. Exploratory factor analysis led to a final two factor model comprised of 31 items that explained $74.9 \%$ of the variance. The factors were labelled as gender discrimination (factor 1) and sexual violence (factor 2); both demonstrated high internal consistency using Cronbach's alpha (factor 1: .987; factor 2: .935). Discussion and conclusion. The SGEVRA is a brief, valid, and reliable instrument for assessing subtle GV among MR.
\end{abstract}

Keywords: Subtle gender-based violence, assessment scale, psychometrics properties, medical residents.

\section{RESUMEN}

Introducción. Los residentes médicos (MR) son un pilar importante para un futuro sistema de salud efectivo. Por ello, es importante estudiar todos los factores a lo largo de su capacitación que puedan influir en su desarrollo profesional, como la violencia de género (GV). Objetivo. Diseñar y evaluar las propiedades psicométricas de la Escala de Violencia Sutil de Género en médicos residentes (SGEVRA, por sus siglas en inglés). Método. El diseño se realizó en dos fases: (1) cualitativa: se entrevistó a tres grupos focales para obtener información sobre la VG durante la capacitación médica; y (2) cuantitativa, donde la información se incorporó al instrumento y se evaluaron las propiedades psicométricas. Resultados. 1,645 residentes médicos (MR) completaron el instrumento. El análisis factorial exploratorio condujo a un modelo final de dos factores compuesto por 31 reactivos que explicaron el $74.9 \%$ de la varianza. Los factores fueron etiquetados como discriminación de género (factor 1) y violencia sexual (factor 2); ambos demostraron una alta consistencia interna con el alfa de Cronbach (factor 1: .987; factor 2: .935). Discusión y conclusión. SGEVRA es un instrumento breve, válido y confiable para evaluar GV en MR.

Palabras clave: Violencia sutil basada en el género, escala de evaluación, propiedades psicométricas, residentes médicos. 


\section{INTRODUCTION}

Human resources are one of the essential supports of the healthcare system. The performance and benefits that this system can deliver depend largely upon the knowledge, skills, and motivation of those responsible for delivering health services.

The quality of education that MRs, as the future healthcare workforce, receive is threatened worldwide by different forms of abuse, including verbal, physical, sexual, and academic harassment (Chávez-Rivera, Ramos-Lira, \& Abreu-Hernández, 2016; Fnais et al., 2013; Fnais et al., 2014; Kulaylat et al., 2017; Li et al., 2010; Nagata-Kobayashi, Maeno, Yoshizu, \& Shimbo, 2009; Castro, 2014; Lawrence et al., 2018; Mulder, Ter Braak, Chen, \& Ten Cate, 2019). These forms of violence against MRs cannot be evaluated in the same way as that of other workers because the culture of medicine is one of "professional dominance" in which systems and individuals are rarely subject to inquiry. Trainees experiencing humiliation and criticism often think that these are part of normal training (Coverdale, Balon, \& Roberts, 2009). In addition, hospitals have a particular hierarchical culture of healthcare that affects the attitudes, values, and behaviours of medical trainees (Ogunsemi, Alebiosu, \& Shorunmu, 2010). As well as hierarchical, medical society is androcentric, reproducing within its structure forms of perception, thought, and action tending to keep women and men (who do not meet the social standards of masculinity) in an undervalued space of inability (Jewkes et al., 2015). Gender interaction patterns and GV during medical specialty training may play a decisive role in the ability to perform as professionals (Camargo, Liu, \& Yousem, 2017; Crebbin, Campbell, Hillis, \& Watters, 2015; Fargen, Drolet, \& Philibert, 2016; Kristoffersson, Andersson, Bengs, \& Hamberg, 2016; Venkatesh et al., 2016). This also includes worse interactions with patients because they function as a reproduction of the same gender structures that gave rise to it (Castro, 2014).

Previous studies analysed medical students (Wilkinson, Gill, Fitzjohn, Palmer, \& Mulder, 2006; Maida et al., 2003) or MRs, but they used questionnaires with three or four items referring to GV (Cohen \& Patten, 2005; Montes-Villaseñor, García-González, Blázquez-Morales, Cruz-Juárez, \& De-San-Jorge-Cárdenas, 2018; Ortiz-León et al., 2014; Sepúlveda-Vildósola, Mota-Nova, Fajardo-Dolci, \& Reyes-Lagunes, 2017; Iglesias-Benavides, Saldívar-Rodríguez, Bermúdez-Barba, \& Guzmán-López, 2005; Nagata-Kobayashi et al., 2009). These instruments are useful in the study of outright discrimination and violence; nevertheless, they are insufficient to identify certain kinds of violence characterised by being subdued, with clever forms of control, and with subtle or insidious repetitive and almost invisible behaviours. These poorly perceived behaviours occurred repeatedly during their training and had an important influence on the learning and future performance of medical specialists. Due to their subtlety, they can be replicated across generations if there is no adequate prevention, detection, and intervention. It is important to develop an instrument that helps to identify this kind of violence, because if medical residents do not recognise incidents of $\mathrm{GV}$, they probably will not report them; as in many low-income countries, there is no specific incidence reporting system of GV.

The aim of the present study was to design and analyse the psychometric proprieties of a specific scale that assesses subtle gender-based violence among MRs.

\section{METHOD}

The ethics and scientific committees of the Universidad Nacional Autónoma de México approved the study procedures. All of the participants took part voluntarily and provided a written informed consent after they received a comprehensive explanation of the study's nature and procedures.

\section{Design of the study}

This study was psychometric, cross-sectional, and analytical, and was conducted among MRs of the UNAM in Mexico City.

\section{Participants}

Design phase of the instrument (qualitative phase focal groups)

MRs were invited to participate in focal groups via email (sent by D.GS., G.H., and L.M). A non-probabilistic sampling, using the intensity approach of all cases required for theoretical saturation, was employed, deliberately seeking variation and richness of data by selecting MRs with the characteristics under study (inclusion criteria: Mexican MR of the UNAM, aged 26-40 years, in the first to the fourth years of medical residency), and who, through their communication, were contributing relevant information about GV among MR. The inclusion of new participants was finished when no additional theoretical information was obtained. Participants were recruited from March 2017 to July 2017.

\section{Instrument testing (validation phase)}

During an annual meeting, MRs with the same aforementioned inclusion criteria were invited personally by the first author to participate. Given the rule of 10 subjects per item to determine the construct validity via factor analysis, a minimal sample of 620 MRs was required. Participants were recruited from September 2017 to February 2018. 


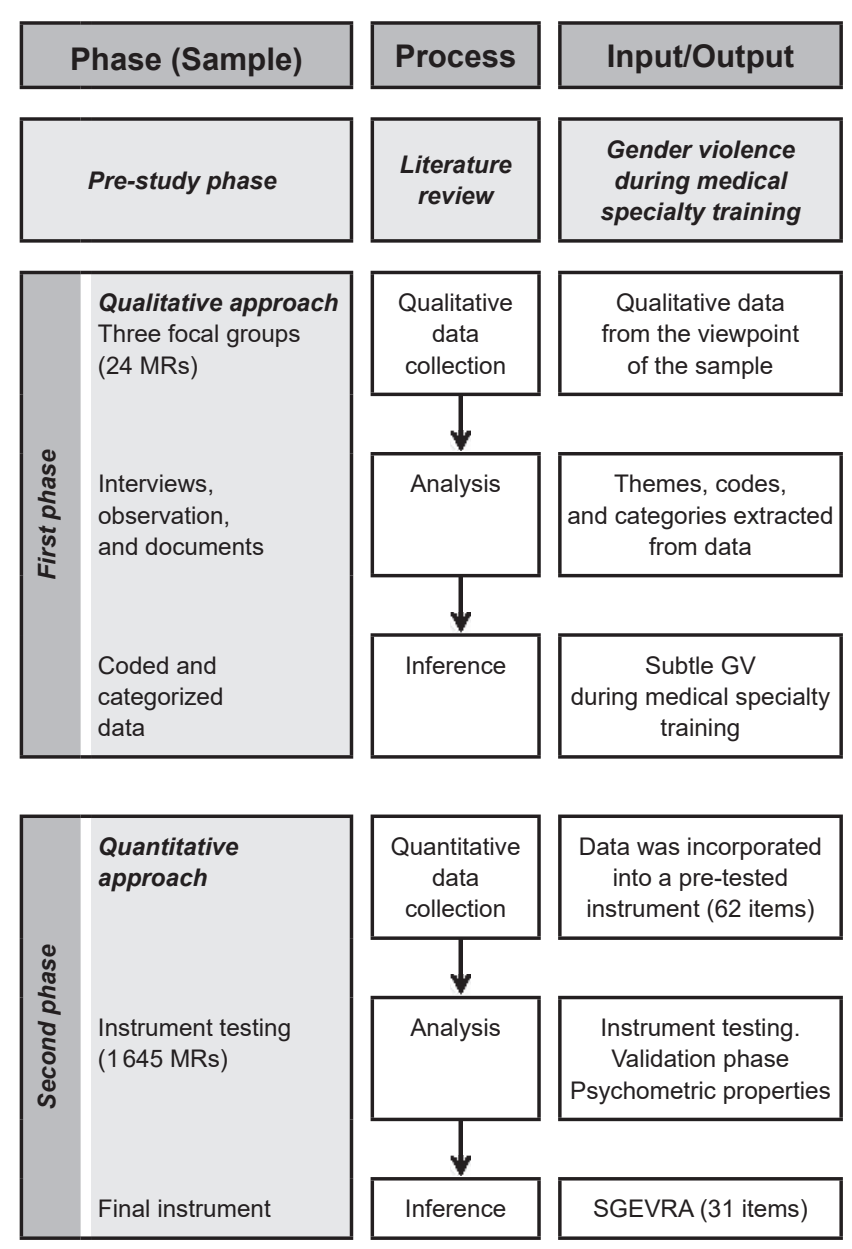

Figure 1. Research process: an exploratory sequential design for the development and psychometric properties of the Subtle Gender-Based Violence among Medical Residents' Assessment Scale (SGEVRA).

\section{Procedure}

The instrument design was based on the mixed method of sequential exploratory design that consisted of two phases (Creswell \& Plano Clark, 2011; Galeano-Marín, 2004) (Figure 1).

(1) Qualitative phase: three focal groups (each one with eight MR) were interviewed twice with a one month interval between the interviews (to facilitate deeper insights and reflection) (Buss-Thofehrn et al., 2013), with a focal group guide (that was built specifically for this study) prepared according to an author's critical literature review (D.GS., I.VH., A.SA., and D.HM) about GV during medical specialty training (Crebbin et al., 2015; Espinar-Ruiz \& Mateo-Pérez, 2007; Fnais et al., 2014; Witte, Stratton, \& Nora, 2006) and was used as a support tool to assist the exploration of key issues with MRs.

A total of 24 MRs participated: $50 \%$ men (from clinical and surgical specialties courses), with an average age of $29.5(S D=2.43$, range $=26-34)$, mostly single $(62.5 \%$, $n=15)$ and without children $(75 \%, n=18)$. The interview was conducted by two research psychiatrists with extensive experience in focus groups (I.VH. and D.GS). The audio-recorded information was transcribed and organised for analysis. An inductive thematic analysis was performed. The contents of the interviews were coded, condensed, and categorised (D.GS. and D.HM separately explored and coded the text) with reference to the research objective (Leech \& Onwuegbuzie, 2008). Subsequently, the data were organised in mutually exclusive categories based on the a priori established categories of the focal group guide.

(2) Quantitative phase: the information was incorporated into a 62-item instrument (D.GS., A.FO., and I.VH): a) 55 items were rated on a 5-point Likert agreement scale (from "totally disagree" to "totally agree"); b) seven items were rated on a good/bad Likert scale (Vagias, 2006) (from very good to very bad). Table 1 provides some examples of the items in the categories.

To test the content validity (Yaghmaie, 2003), four gender and sexuality experts (J.RR., A.SG., M.GL, and A.SA), with at least three years' experience in the field, were asked to rate on a four-point scale each item based on relevance, clarity, simplicity, and ambiguity. Items with a Content Validity Index (CVI) (Waltz \& Bausell, 1981) over .80 were retained (mean $=.89, S D=.11)$. Two items were discarded as the experts considered they evaluated discrimination based on sexual orientation. Corrections of style were made in the writing of items with inclusive language, thus integrating a final 60 -item instrument divided into two dimensions: gender discrimination (GD) (31 items) and sexual violence (SV) (29 items). The responses were transformed into quantitative variables on a scale of 1 to $5(1=$ strongly disagree, very good; $5=$ totally agree, very bad). Subscale scores were calculated as follows: GD was the result of the sum of the scores in each of the items with the Likert agreement scale (31 items) and SV was the sum of the scores of each of the 29 items.

\section{Instrument testing}

A pilot study of the instrument was conducted on 1900 MRs of the UNAM, of which 1645 physicians (from clinical and surgical specialisation courses) answered the complete instrument, representing an $86 \%$ response rate. Overall, $56 \%$ $(n=921)$ were women, with an average age of 30.6 years $(S D=2.94$, range $=25-39)$. Most of the participants were single at the time of the study $(96.4 \%, n=1586)$, without children $(97.8 \%, n=1610)$, and attending the first two years of their medical specialty (first year $=37.2 \%, n=612$; second year $=38.7 \%, n=636$ ). The average response time was $17.5(S D=2.3)$ minutes. 
Table 1

Examples of relevant categories of the focal group, objectives of each category, testimonials, and the instrument's items

\begin{tabular}{|c|c|c|c|}
\hline Categories & Objectives & Example of testimonial & Example of items \\
\hline \multicolumn{4}{|c|}{ Gender discrimination } \\
\hline $\begin{array}{l}\text { Academic perfor- } \\
\text { mance evaluation }\end{array}$ & $\begin{array}{l}\text { To explore differences in } \\
\text { the evaluation of academ- } \\
\text { ic performance with argu- } \\
\text { ments related to gender. }\end{array}$ & $\begin{array}{l}\text { "The first day he told us: you guys } \\
\text { should not be here, you should look for } \\
\text { something more manly (male R1D)". }\end{array}$ & $\begin{array}{l}\text { My superiors (chief resident, medical director, as- } \\
\text { signed doctor, etc.) negatively value my abilities } \\
\text { and academic merits with gender arguments. }\end{array}$ \\
\hline Professional future & $\begin{array}{l}\text { To know the differences } \\
\text { in the perception of the } \\
\text { professional future in their } \\
\text { specialty. }\end{array}$ & $\begin{array}{l}\text { "Oh, little doctor so much effort, if no- } \\
\text { body is going to want to go with a wom- } \\
\text { an, the good thing is that she has some- } \\
\text { one to keep her" (female, R1U). }\end{array}$ & $\begin{array}{l}\text { When requiring care from a surgical specialty } \\
\text { (for example, urology, surgery, and orthopae- } \\
\text { dics), I prefer to receive care from a woman. }\end{array}$ \\
\hline Favouritism & $\begin{array}{l}\text { To know if there is a prefer- } \\
\text { ence for some kind of gen- } \\
\text { der to carry out some pro- } \\
\text { cedures of the specialty. }\end{array}$ & $\begin{array}{l}\text { "There was an occasion that they told } \\
\text { me I would prefer if your partner does it } \\
\text { because it is a more delicate and metic- } \\
\text { ulous job" (male R3O)*. }\end{array}$ & $\begin{array}{l}\text { My superiors (chief resident, medical manage- } \\
\text { ment, etc.) based on gender arguments perform } \\
\text { an inequitable distribution of the allocation of } \\
\text { procedures considered essential in the training } \\
\text { of my specialty. }\end{array}$ \\
\hline \multicolumn{4}{|l|}{ Sexual violence } \\
\hline $\begin{array}{l}\text { Unwelcome verbal } \\
\text { advances }\end{array}$ & $\begin{array}{l}\text { To evaluate the presence } \\
\text { of verbal harassment of } \\
\text { sexual content. }\end{array}$ & $\begin{array}{l}\text { "For example, your partner, with that little } \\
\text { waist and those little hands, I let her ex- } \\
\text { plore what she needs and let her make } \\
\text { me sleep beautifully" (female, R3A)*. }\end{array}$ & $\begin{array}{l}\text { When I'm with my superior (chief resident, medi- } \\
\text { cal director, assigned doctor, etc.), she/he usual- } \\
\text { ly has conversations with sexual content alluding } \\
\text { to my person, generating a feeling of discomfort. }\end{array}$ \\
\hline $\begin{array}{l}\text { Unwanted physical } \\
\text { advances }\end{array}$ & $\begin{array}{l}\text { To explore the presence of } \\
\text { physical contact with sex- } \\
\text { ual connotations. }\end{array}$ & $\begin{array}{l}\text { "I had the file on my legs and my assign- } \\
\text { ee took it telling me any touch is purely } \\
\text { professional" (male, R2Ps)*. }\end{array}$ & $\begin{array}{l}\text { I have been experienced unwanted sexual con- } \\
\text { tact during clinical, surgical, or academic ac- } \\
\text { tivities (for example, stroking my leg, neck, or } \\
\text { breast, etc.). }\end{array}$ \\
\hline
\end{tabular}

${ }^{*} \mathrm{R}=$ Resident, $\mathrm{A}=$ Anaesthesiology, $\mathrm{D}=$ Dermatology, $\mathrm{O}=$ Oncology, $\mathrm{Ps}=$ Psychiatry, and $\mathrm{U}=$ Urology.

\section{Statistical analysis}

The procedure for testing the construct validity and internal consistency of the instrument was as follows (Rodríguez-Pérez, Valencia-Flores, Reyes-Lagunes, \& LaraMuñoz, 2013): (1) the frequency analysis test and item discrimination index for each item was performed. Items with a single response on more than $90 \%$ of the cases were eliminated as well as those with moderate discrimination indexes (< .30). (2) An item total correlation was obtained. Items with moderate indexes $(<.20)$ were eliminated. As a second procedure, we determined the construct validity of the SGEVRA with an exploratory factor analysis with varimax rotation; the suitability of the data for structure detection was indicated by the Kaiser-Meyer-Olkin and Bartlett tests. Cattell's Scree Plot was also obtained. Items with communalities greater than .70 were retained and allocated to factors (Hair, Black, Babin, \& Anderson, 2010). Reliability was obtained by determining the internal consistency of the SGEVRA through Cronbach's alpha. All statistical analyses were performed using the Statistical Package for the Social Sciences (SPSS), version 21. Statistical significance for all analyses was set at an alpha level of $<.05$ (two-tailed).

\section{RESULTS}

\section{Item frequency and discrimination indices}

Seven items of the original 60 proposed were eliminated as more than $90 \%$ of the participants answered one single response for the items. From the remaining 53, the item discrimination indices ranged from good to excellent with values between .34 to .86 . These items were included in the subsequent factor analysis.

\section{Psychometric properties of the SGEVRA}

The results of the varimax rotation of the instrument's 53 items accounted for $71.2 \%$ of the variance. The rotated factor matrix exhibited four factors. Factors 3 and 4 consisted of a single item and therefore both were eliminated.

Of the remaining 51 items, 15 showed communalities lower than .70 and were also eliminated. The rationality of those communalities may be that 11 of the items were raised in a reverse grammatical sense. Finally, five additional items were eliminated as they loaded into a theoretical construct different from the one for which they were originally designed.

After these modifications, a second factor analysis was performed. The Kaiser-Meyer-Olkin sampling adequacy was .87 and a significant Bartlett test $(<.001)$ was obtained. 
Table 2

Factor loading of the instrument in a two-factor model, Varimax

Factor loading

Final instrument

Factor $1 \mathrm{GD}$ Factor $2 \mathrm{SV}$

1. I have been informed of the means (area in charge, regulation, code, statute) to sanction gender discrimination in my institution.

.839

2. When requiring care from a surgical specialty (for example, urology, surgery, orthopaedics), I prefer to receive care from a woman.

3. I have been informed of the means (area in charge, regulation, code, statute) to punish harassment and sexual violence in my work institution.

4. My superiors (for example, chief resident, medical director, etc.) assign me procedures or activities that are far below my abilities and level of training, based on gender arguments.

5. I have been treated negatively, with gender arguments (more night shifts, more classes or sessions, less attendance at conferences, etc.).

6. How would you rate in ascending order (1 bad, 5 good) the performance of women in research work (methodological quality, importance, relevance, and number of publications)?

7. Positions of greater hierarchy are occupied more frequently by men (for example, chief resident, senior surgeon, medical director, and hospital director).

8. My superiors (for example, chief resident, medical management, etc.), based on gender arguments, perform an inequitable distribution of the allocation of procedures considered essential in the training of my specialty.

9. I have received offensive gender jokes from other medical residents.

10. When requiring attention related to a clinical specialty, (for example, internal medicine, dermatology, paediatrics), I prefer to receive attention from a man.

11. Some patients negatively value my professional preparation or/and my clinical or surgical skills based on gender arguments.

12. My superiors (for example, chief resident, medical director, assigned doctor, etc.) negatively value my abilities and academic merits with gender arguments.

13. When there are important clinical or research sessions, I am asked to do non-academic activities during the session (serving coffee, cleaning the office, etc.).

14. The nursing staff has a differential treatment of gender and tends to value my abilities and effort negatively.

15. During supervisions or in front of other medical residents or patients, my superiors (chief resident, medical director, assigned doctor, etc.) made gender offensive remarks.

16. My superiors (chief resident, medical director, assigned doctor, etc.) with gender arguments, mark differences in learning opportunities (personalised supervision during clinical or surgical procedures, assign better clinical cases, private classes, and better studying material).

17. My superiors (chief resident, medical director, assigned doctor, etc.) differentially assign the workload during night shifts (number of patients, classes, procedures, etc.) with gender arguments.

18. During the process of admission to my specialty, it was more important to consider gender than professional skills or academic merits.

19. Other medical residents negatively value my academic ability, my clinical or surgical skills, and my work proposals or attitudes with gender arguments.

20. I have received offensive gender jokes from patients or relatives of patients.

21. I have been treated in an unfavourable way due to pregnancy, childbirth, or any medical condition related to both or I have witnessed this behaviour toward a pregnant colleague.

.886

.863

.841

.887

.839

.834

.898

.902

.913

.864

.859

.892

.884

.846

.896

.889

.878

.881

.893

22. When l'm with my superior (chief resident, medical director, assigned doctor, etc.), she/he usually has conversations with sexual content alluding to my person, generating a feeling of discomfort.

23. I have noticed that during my clinical, surgical, or academic activities, my superiors usually look at me in a way that makes me feel uncomfortable (with sexual intentions).

24. I have received offensive jokes related to sexual issues (for example, my sex life) by my superiors during my clinical supervision or in front of patients or other medical residents.

25. I have received against my will indirect proposals to establish a sexual relationship from my superiors, despite my efforts to reject them.

26. I have received comments from my superiors about avoiding punishment or additional workload in exchange for "sexual favours."

27. I have received comments from other medical residents about not mentioning my mistakes to my superiors in exchange for sexual contact. 


\begin{tabular}{|c|c|c|}
\hline \multirow[b]{2}{*}{ Final instrument } & \multicolumn{2}{|c|}{ Factor loading } \\
\hline & Factor $1 \mathrm{GD}$ & Factor $2 S D$ \\
\hline $\begin{array}{l}\text { 28. I have received against my will proposals, direct or indirect, to establish a sexual relationship from other } \\
\text { medical residents, despite my efforts to reject them. }\end{array}$ & & .741 \\
\hline $\begin{array}{l}\text { 29. I have repeatedly experienced unwanted sexual contact during clinical, surgical, or academic activities (for } \\
\text { example, stroking my leg, neck, or breast, etc.). }\end{array}$ & & .800 \\
\hline $\begin{array}{l}\text { 30. I have noticed that during my clinical, surgical, or academic activities, other medical residents usually look } \\
\text { at me in a way that makes me feel uncomfortable (with sexual intentions). }\end{array}$ & & .771 \\
\hline $\begin{array}{l}\text { 31. When I am with other medical residents, they usually have conversations with sexual content alluding to my } \\
\text { person, generating a feeling of discomfort. }\end{array}$ & & .702 \\
\hline Eigenvalue & 18.22 & 5.023 \\
\hline Variance (\%) & 58.78 & 16.21 \\
\hline
\end{tabular}

The analysis showed two clear factors that corresponded to the original two designed domains that accounted for $74.98 \%$ of the variance. The first factor $(58.78 \%$ of the variance) contained 21 statements with factor loadings above .83. The second factor ( $16.21 \%$ of the variance) involved 10 statements that loaded at the .70 level or above (Table 2).

The reliability of the SGEVRA obtained by assessing the internal consistency was high. Cronbach's alpha for the 21-item factor 1 (GD) was .98, and for the 10-item factor 2 (SV) was .93.

\section{DISCUSSION AND CONCLUSION}

The present study presents psychometric evidence of the validity and reliability of the SGEVRA. The exploratory factor analysis corroborated the adequacy of the two-factor model with good fit indexes for all of the items, whose sum was used as a global measure of the phenomenon. The reliability analysis showed high values of internal consistency.

At the beginning of the focal group, many participants (both sexes) stated that gender did not matter, but they later described numerous subtle experiences of constraining gendered preconceptions and discriminatory treatment. Why did the MRs have difficulties recognising GV during their training? One explanation might be the widespread, everyday communication of gender beliefs combined with the MRs' normalisation of sexism and gender discrimination. Studies showed that medical residents often do not report an incident of abuse because they are unaware of what qualifies as abuse (Al-Shafaee et al., 2013; Nagata-Kobayashi et al., 2009). They rationalise intimidation and harassment as being a "functional educational tool" (Musselman, MacRae, Reznick, \& Lingard, 2005) or they lack knowledge on how and to whom they should report incidents (Al-Shafaee et al., 2013; Coverdale et al., 2009; Nagata-Kobayashi et al., 2009). Studies analysing medical residents' knowledge of the reporting process showed that only approximately one-half knew the process required to report such mistreatment (Crutcher, Szafran, Woloschuk, Chatur, \& Hansen, 2011; Cohen \& Patten, 2005). Additionally, some authorities (heads of teaching and academic directors) contemplate these acts as being irrelevant or "normal" (Castro, 2014). The aforementioned constitutes an important finding during the construction of the instrument. However, it could also be considered that one of the benefits of the instrument is the fact that through the reading of items with specific examples of this subtle type of GV, MRs may notice behaviours that would go unnoticed if not directly asked.

The gender experts discarded two items: (1) "your superiors treat you badly because of your sexual orientation" and (2) "you have received offensive jokes related to your sexual orientation by your superiors or colleagues." Those items were created to assess unwanted attempts to draw MRs into a discussion of sexual matters as a part of sexual violence (Fitzgerald, Gelfand, \& Drasgow, 1995), but the group of experts said that those items were evaluating violence based on sexual orientation, which is a type of violence often referred to as homophobic and transphobic violence.

Subsequently, seven items were eliminated, as more than $90 \%$ of the participants answered one single response for them: (1) "All people, without distinction of gender, can develop the same activities within a hospital," (2) "In order not to appear sexist, many men are inclined to overprotect women and overload men with work," (3) "In my day to day, I apply my beliefs about gender equity," (4) "I consider that the differences in opportunities due to gender are justified," (5) "I think there are medical specialties that are more suitable for people of a specific gender," (6) "I consider status differences between people of different genders are justified by biological reasons," and (7) "I think in managerial positions, where political and diplomatic skills are required in addition to academic ones, men are better leaders than women." The almost exclusive answer to these items may be related to the inter- 
pretation of them as factual (Haladyna \& Rodríguez, 2013) and some may have triggered social desirability concerns (Kreuter, Presser, \& Tourangeau, 2008; Tourangeau \& Yan, 2007). In other words, MRs underreport undesirable opinions because there are social norms governing some beliefs and/or attitudes so that the participants may misrepresent themselves to appear to comply with these norms (Kreuter et al., 2008). This should be taken into consideration in future studies.

Additionally, 22 items were eliminated: (1) two because the first rotated factor matrix exhibited four factors (two consisted of a single item): "Although before there was discrimination based on gender, at present there are no differences in treatment for this reason." This may load in a different factor because it evaluated the general opinion of the MRs on GD but did not address specific attitudes (such as the rest of the items in the factor). The second item was: "Some family members of patients negatively value your abilities, effort, work proposals, or attitudes with gender arguments." This item probably loads in a different factor as the sentence refers to a relative of a patient and not a member of the healthcare staff (other resident doctors, chief residents, and nurses), making it difficult to understand the meaning of the question. Another possibility is that the medical residents thought that the question evaluated a different construct such as public recognition of their medical work. (2) A total of 15 items were redundant and showed communalities lower than 0.70 , so they were also discarded (Hair et al., 2010). (3) The remaining five items were eliminated as they loaded into a theoretical construct different from the one for which they were originally designed. The following two questions: "Have you noticed that your superiors tend to look at you with sexual intentions and that makes you feel bad?" and "Have you received comments from your superiors about rewards or academic incentives in exchange for sexual favours?" were designed as part of SV, but probably loaded in a different factor as some of the medical residents considered them a form of GD. The following questions were designed as part of the GD factor but were loaded in the SV factor: "In your work area, men discriminate more for gender reasons" is perhaps an example of confusion between the concept of GV and SV. "How would you rate in ascending order the performance of women in medical-clinical areas (for example, internal medicine)" and "How would you rate in ascending order the performance of men in surgical areas" are perhaps examples of confusion in the change in the response scale (Haladyna \& Rodríguez, 2013).

Some limitations should be considered. (1) The SGEVRA does not have a scale to evaluate the frequency of SV and/or GD. (2) It does not include the specific context of a gay MR being harassed by a gay or non-gay MR. (3) It does not include items about GV's impact on quality of work. (4) As a self-reported instrument, it relies on the honesty of the participants; factors such as: reporting on either powerful people, people with whom they compete professionally, or people they are bound to serve; fear of negative implications and trauma can interfere with the responses. This study had several strengths, such as enrolling over 1669 participants (24 for the focus groups and 1645 for the instrument testing). Items for the instrument were generated from an indepth literature review and focal group interview with the participation of residents of both sexes as well as surgical, clinical, and diagnostic specialties, which allowed the MRs to express their views, attitudes, beliefs, and experiences about both phenomena, and the latter was reviewed by a panel of gender experts. These steps allowed the development of an instrument based on both views (MRs and gender-sexual experts). Further studies should use a confirmatory factor analysis to evaluate the distribution of the items and the adequacy of the two proposed dimensions of the SGEVRA. Also, a cross-cultural validation should be performed including cultural factors that may influence the perception or reporting of the phenomenon.

The consequences of GV often leave indelible scars on the victims and cause strong deterioration in mental health: anxiety, depression, panic attacks, sleep disorders, headaches, cognitive disorders related to attention and memory, feelings of vulnerability, and difficulties in establishing relationships, among others, negatively impact work performance.

It is necessary to provide MRs, teachers, and supervisors with theoretical concepts and knowledge to help them recognise subtle GV, because if they do not recognise incidents of GV, they probably will not report them. Therefore, the SGEVRA as a self-rated questionnaire is a very attractive solution for screening purposes.

SGEVRA is a valid and reliable instrument for measuring a frequent phenomenon that may have important personal and professional implications in this population (subtle GV during medical residency). It is important not to forget that any form of abuse is a serious threat to an environment that allows them to professionally flourish and maintain the highest quality healthcare system possible. Teaching hospitals and medical schools should not forget that in order to guarantee quality medical care, they must guarantee MRs' physical and mental health.

\section{Funding}

Dr. Diana Guízar-Sánchez received a grant from the Consejo Nacional de Ciencia y Tecnología (CONACYT) as a doctoral student in health sciences at the Universidad Nacional Autónoma de México.

\section{Conflict of interests}

The authors declare they have no conflict of interests.

\section{Acknowledgements}

The authors thank the study participants who provided their time for this research and the following colleagues for their valuable contributions and comments: Jesús Abrahán Ruiz Rosas, MD; Arturo Sandoval Guerra, PSM; Mario Fausto Gómez Lamont, MSc; Francisco Romo-Nava, $\mathrm{PhD}$; and Lugowski-Rivero Czeslaw Kristofer, MEng. 


\section{REFERENCES}

Al-Shafaee, M., Al-Kaabi, Y., Al-Farsi, Y., White, G., Al-Maniri, A., Al-Sinawi, H., \& Al-Adawi, S. (2013). Pilot study on the prevalence of abuse and mistreatment during clinical internship: a cross-sectional study among first year residents in Oman. BMJ Open, 3(2), e002076. doi: 10.1136/bmjopen-2012-002076

Buss-Thofehrn, M., López-Montesinos, M. J., Rutz-Porto, A., Coelho Amestoy, S., Oliveira Arrieira, I. C. D., \& Mikla, M. (2013). Grupo focal: una técnica de recogida de datos en investigaciones cualitativas. Index de Enfermería, 22(1-2), 75-78. doi: 10.4321/S1132-12962013000100016

Camargo, A., Liu, L., \& Yousem, D.M. (2017). Sexual harassment in radiology. Journal of the American College of Radiology, 14(8), 1094-1099. doi: 10.1016/j. jacr.2017.02.054

Castro, R. (2014). Génesis y práctica del habitus médico autoritario en México. Revista Mexicana de Sociología, 76(2), 167-197.

Chávez-Rivera, A., Ramos-Lira, L., \& Abreu-Hernández, L. (2016). Una revisión sistemática del maltrato en el estudiante de medicina. Gaceta Médica México, 152(6), 796-811.

Cohen, J. S, \& Patten, S. (2005). Well-being in residency training: A survey examining resident physician satisfaction both within and outside of residency training and mental health in Alberta. BMC Medical Education, 5(21), 1-11. doi: 10.1186/1472-6920-5-21

Coverdale, J. H., Balon, R., \& Roberts, L. W. (2009). Mistreatment of trainees: verbal abuse and other bullying behaviors. Academic Psychiatry, 33(4), 269-273. doi: 10.1176/appi.ap.33.4.269

Crebbin, W., Campbell, G., Hillis, D. A., \& Watters, D. A. (2015). Prevalence of bullying, discrimination and sexual harassment in surgery in Australasia. ANZ Journal of Surgery, 85(12), 905-909. doi: 10.1111/ans.13363

Creswell, J. W., \& Plano Clark, V. L. (2011). Designing and conducting mixed methods research. Los Angeles: SAGE Publications. ISBN 1412975174

Crutcher, R. A., Szafran, O., Woloschuk, W., Chatur, F., \& Hansen, C. (2011). Family medicine graduates' perceptions of intimidation, harassment, and discrimination during residency training. BMC Medical Education, 11(1), 88. doi: $10.1186 / 1472-6920-11-88$

Espinar-Ruiz, E., \& Mateo-Pérez, M. Á. (2007). Violencia de género: Reflexiones conceptuales, derivaciones prácticas. Papers: Revista de Sociología, (86), 189-201.

Fargen, K. M., Drolet, B. C., \& Philibert, I. (2016). Unprofessional behaviors among tomorrow's physicians: Review of the literature with a focus on risk factors, temporal trends, and future directions. Academic Medicine, 91(6), 858-864. doi: 10.1097/ACM.0000000000001133

Fitzgerald, L. F, Gelfand, M. J, \& Drasgow, F. (1995). Measuring sexual harassment: Theoretical and psychometric advances. Basic and Applied Social Psychology, 17(4), 425-455. doi: 10.1207/s15324834basp1704_2

Flores-Reynoso, S., Medina-Dávalos, R., \& Robles-García, R. (2011). Estudio de traducción al español y evaluación psicométrica de una escala para medir el estigma internalizado en pacientes con trastornos mentales graves. Salud Mental, 34(4), 333-339.

Fnais, N., Al-Nasser, M., Zamakhshary, M., Abuznadah, W., Al-Dhukair, S., Saadeh, M., ... BinAhmed, A. (2013). Prevalence of harassment and discrimination among residents in three training hospitals in Saudi Arabia. Annals of Saudi Medicine, 33(2), 134-139. doi: 10.5144/0256-4947.2013.134

Fnais, N., Soobiah, C., Chen, M. H., Lillie, E., Perrier, L., Tashkhandi, M., ... Tricco, A. C. (2014). Harassment and discrimination in medical training: a systematic review and meta-analysis. Academic Medicine, 89(5), 817-827. doi: 10.1097/ ACM.0000000000000200

Galeano-Marín, M. E. (2004). Diseño de proyectos en la investigación cualitativa. Medellín, Colombia: Fondo Editorial Universidad EAFIT, p 40. ISBN: 9588173-78-7

Hair, J. F., Black, W. C., Babin, B. J., \& Anderson, R. E., (2010). Multivariate data analysis (7th ed.). Upper Saddle River, NJ: Prentice-Hall. ISBN 0138132631

Haladyna, T. M., \& Rodriguez, M. C. (2013). Developing and validating test items. New York, NY: Routledge. ISBN 9780415876056

Iglesias-Benavides, J. L., Saldívar-Rodríguez, D., Bermúdez-Barba, V., \& GuzmánLópez, A. (2005). Maltrato del estudiante de medicina. Percepción de 404 alumnos de cuarto, quinto y sexto años de la carrera. Medicina Universitaria, 7(29), 191-202

Jewkes, R., Morrell, R., Hearn, J., Lundqvist, E., Blackbeard, D., Lindegger, G., ... Gottzén, L. (2015). Hegemonic masculinity: Combining theory and practice in gender interventions. Culture, Health \& Sexuality, 17(sup2), 112-127. doi: 10.1080/13691058.2015.1085094

Kreuter, F., Presser, S., \& Tourangeau, R. (2008). Social desirability bias in CATI, IVR, and Web Surveys: The effects of mode and question sensitivity. Public Opinion Quarterly, 72(5), 847-865. doi: 10.1093/poq/nfn063
Kristoffersson, E., Andersson, J., Bengs, C., \& Hamberg, K. 2016. Experiences of the gender climate in clinical training - a focus group study among Swedish medical students. BMC Medical Education, 16(1), 283. doi: 10.1186/s12909016-0803-1

Kulaylat, A. N., Qin, D., Sun, S. X., Hollenbeak, C. S., Schubart, J. R., Aboud, A. J., ... Han, D. C. (2017). Perceptions of mistreatment among trainees vary at different stages of clinical training. BMC Medical Education, 17(1), 14. doi: 10.1186/s12909-016-0853-4

Lawrence, C., Mhlaba, T., Stewart, K. A., Moletsane, R., Gaede, B., \& Moshabela, M. (2018). The hidden curricula of medical education: a scoping review. Academic Medicine, 93(4), 648-656. doi: 10.1097/ACM.0000000000002004

Leech, N. L., \& Onwuegbuzie, A. J. (2008). Qualitative data analysis: A compendium of techniques and a framework for selection for school psychology research and beyond. School Psychology Quarterly, 23(4), 587-604. doi: 10.1037/10453830.23.4.587

Li, S. F., Grant, K., Bhoj, T., Lent, G., Garrick, J. F., Greenwald, P., ... Cowan, E. (2010). Resident experience of abuse and harassment in emergency medicine: Ten years later. The Journal of Emergency Medicine, 38(2), 248-252. doi: 10.1016/j.jemermed.2008.05.005

Maida, A. M., Vásquez, A., Herskovic, V., Calderón, J. L., Jacard, M., Pereira, A., \& Widdel, L. (2003). A report on student abuse during medical training. Medical Teacher, 25(5), 497-450. doi: 10.1080/01421590310001606317

Montes-Villaseñor, E., García-González, J., Blázquez-Morales, M. S. L., CruzJuárez, A., \& De-San-Jorge-Cárdenas, X. M. (2018). Exposición a la violencia durante la formación profesional de los residentes médicos. CienciaUAT, 12(2), 54-66.

Mulder, H., Ter Braak, E., Chen, H. C., \& Ten Cate, O. (2019). Addressing the hidden curriculum in the clinical workplace: A practical tool for trainees and faculty. Medical Teacher, 41(1), 36-43. doi: 10.1080/0142159X.2018.1436760

Musselman, L. J., MacRae, H. M., Reznick, R. K., \& Lingard, L. A. (2005). 'You learn better under the gun': Intimidation and harassment in surgical education. Medical Education, 39(9), 926-934. doi: 10.1111/j.1365-2929.2005.02247.x

Nagata-Kobayashi, S., Maeno, T., Yoshizu, M., \& Shimbo, T. (2009). Universal problems during residency: Abuse and harassment. Medical Education, 43(7), 628-636. doi: 10.1111/j.1365-2923.2009.03388.x

Ogunsemi, O. O., Alebiosu, O. C., \& Shorunmu, O. T. (2010). A survey of perceived stress, intimidation, harassment and well-being of resident doctors in a Nigerian teaching hospital. Nigerian Journal of Clinical Practice, 13(2), 183-186.

Ortiz-León, S., Jaimes-Medrano, A. L., Tafoya-Ramos, S. A., Mujica-Amaya, M. L., Olmedo-Canchola, V. H., \& Carrasco-Rojas, J. A. (2014). Experiencias de maltrato y hostigamiento en médicos residentes. Cirugía y Cirujanos, 82(3), 290-301.

Rodríguez-Pérez, V., Valencia-Flores, M., Reyes-Lagunes, I., \& Lara-Muñoz, M. C. (2013). Adaptación y validación psicométrica del Cuestionario de Consecuencias Funcionales del Dormir (Functional Outcomes Sleep Questionnaire [FOSQ]) en habitantes de la Ciudad de México. Salud Mental, 36(4), 307-313. doi: 10.17711/SM.0185-3325.2013.037

Sepúlveda-Vildósola, A. C., Mota-Nova, A. R., Fajardo-Dolci, G. E., \& ReyesLagunes, L. I. (2017). Workplace bullying during specialty training in a pediatric hospital in Mexico: A little-noticed phenomenon. Revista Médica del Instituto Mexicano del Seguro Social, 55(S1), 92-101.

Tourangeau, R., \& Yan, T. (2007). Sensitive questions in surveys, Psychological Bulletin, 133(5), 859-883. doi: 10.1037/0033-2909.133.5.859

Vagias, W. M. (2006). Likert-type scale response anchors. Clemson International Institute for Tourism \& Research Development, Department of Parks, Recreation and Tourism Management. Clemson: Clemson University.

Venkatesh, B., Corke, C., Raper, R., Pinder, M., Stephens, D., Joynt, G., ... Varghese, B. (2016). Prevalence of bullying, discrimination and sexual harassment among trainees and Fellows of the College of Intensive Care Medicine of Australia and New Zealand. Critical Care and Resuscitation, 18(4), 230-234.

Waltz, C. F., \& Bausell, R. B. (1981). Nursing research: Design, statistics and computer analysis. Philadelphia: FA Davis Company. ISBN: 0803690401

Wilkinson, T. J., Gill, D. J., Fitzjohn, J., Palmer, C. L., \& Mulder, R. T. (2006). The impact on students of adverse experiences during medical school. Medical Teacher, 28(2), 129-135. doi: 10.1080/01421590600607195

Witte, F. M., Stratton, T. D., \& Nora, L. M. (2006). Stories from the field: Students' descriptions of gender discrimination and sexual harassment during medical school. Academic Medicine, 81(7), 648-654. doi: 10.1097/01. ACM.0000232421.04170.d2

Yaghmaie, F. (2003). Content validity and its estimation. Journal of Medical Education, 3(1), 25-27. doi: 10.22037/jme.v3i1.870 